\title{
Clinical Trial Candidate
}

National Cancer Institute

\section{Source}

National Cancer Institute. Clinical Trial Candidate. NCI Thesaurus. Code C162701.

A patient who meets the eligibility criteria for participation in a clinical trial. 